\title{
THE SPATIO-TEMPORAL PATTERN OF THE MID-HOLOCENE THERMAL MAXIMUM
}

\begin{abstract}
LJUNGQVIST, F.C. (2011): The Spatio-Temporal Pattern of the Mid-Holocene Thermal Maximum. Geografie, 116, No. 2, pp. 91-110. - This article presents a review of the spatio-temporal pattern of the mid-Holocene Thermal Maximum as it occurs in 60 different reconstructions of annual mean temperature from locations around the globe. The geographical coherency of multi-centennial periods with annual mean temperatures at least $1^{\circ} \mathrm{C}$ and $2^{\circ} \mathrm{C}$ above the pre-industrial ( 1750 AD) equivalents are presented. Although the reconstructions show a heterogeneous temperature pattern for the period c. 10-8 ka BP, a rather coherent period of temperatures exceeding the pre-industrial ones are seen for c. 8-4 ka BP. The onset of the Neoglaciation takes place 4-3 ka BP and cumulates during the Little Ice Age (c. 1300-1900 AD). Overall, our review points towards a more homogeneous mid-Holocene Thermal Maximum than hitherto reported. However, the still limited data coverage, especially for the Southern Hemisphere, restricts the possibility to draw any firm conclusion regarding the amplitude and spatio-temporal pattern of the maximum midHolocene warming.

KEY WORDS: Mid-Holocene Thermal Maximum - Neoglaciation - palaeoclimatic records temperature proxy data - climate variability - temperature reconstructions - global warming.
\end{abstract}

\section{Introduction}

It has long been known that the earth experienced rather high temperatures during the mid-Holocene period (c. 8 to $5 \mathrm{ka} \mathrm{BP}$ ), especially during the summer at high latitudes in the Northern Hemisphere (see, e.g., Lamb 1977). In some regions, such as Greenland, Scandinavia, the North Atlantic, northern Siberia, eastern China, and Tasmania, certain seasonal temperatures were several degrees Celsius higher than today (He et al. 2004; Kim et al. 2004; MacDonald et al. 2000; Seppä et al. 2009; Vinther et al. 2009; Xia et al. 2001). This warm period is usually referred to as the Mid-Holocene Thermal Maximum or the Mid-Holocene Climate Optimum (sometimes also referred to as Altithermal, Hypsithermal or Holocene Megathermal). This warming, and the subsequent cooling (the Neoglaciation), was primarily caused by changes in the Earth's orbital tilt and precession (Berger, Loutre 1991; Renssen et al. 2009; Wanner, Bütikofer 2008). The direct results of these orbital changes during the mid-Holocene, according to state-of-the-art General Circulation Models and Energy Balance Models, should have been a substantial warming during the Northern Hemisphere summer and perhaps a slight cooling during the winter, whereas the Southern Hemisphere should have experienced somewhat cooler summers and warmer winters (Solomon et al., eds. 2007). How- 
ever, several strong positive feedbacks in the climate system (i.e. the ice-albedo feedback and the sea-ice insolation feedback) and a large-scale reorganization of the latitudinal heat transport seem to have caused a more global warming. Moreover, the orbital changes alone should have resulted in maximum Northern Hemisphere summer heating already c. $11 \mathrm{ka}$ BP. However, this was not the case. The cooling effect of the remaining melting ice-sheets from the last glacial period led to a delayed mid-Holocene Thermal Maximum by several thousand years (MacDonald et al. 2000; Davis et al. 2003; Kaufman et al. 2004; Widmann 2009). In a recent review of available proxy records, Shakun and Carlson (2010) found that the warmest conditions during the Holocene occurred in the Northern Hemisphere c. $8 \pm 3.2 \mathrm{ka}$ BP and in the Southern Hemisphere c. $7.4 \pm 3.7 \mathrm{ka} \mathrm{BP}$.

No quantitative reconstruction of the Holocene temperature evolution on a global scale has yet been attempted and only one such reconstruction for the Northern Hemisphere has been published. The reconstruction of annual mean air temperature by Klimenko, Klimanov, Fedorov (1996) shows a variability of $4-5^{\circ} \mathrm{C}$ during the Holocene, with a maximum $1^{\circ} \mathrm{C}$ above modern temperatures shortly after $6000 \mathrm{BP}$, but has rarely been cited in the literature since no description is given of the method and data used. On the other hand, a number of quantitative reconstructions and syntheses of temperature (and/or precipitation) changes during the Holocene on a regional scale have been published during the last decade.

Cheddadi et al. (1997) attempted to estimate the climate in Europe 6000 BP from pollen data. They found that both summer and winter temperatures were considerably higher in northern Europe than now but also that the climate $6000 \mathrm{BP}$ was much colder in the Mediterranean region than today. Davis et al. (2003) published a quantitative pollen climate reconstruction using a four-dimensional gridding procedure of more than 500 pollen sites that essentially confirmed the results from Cheddadi et al. (1997), although they found less mid-Holocene winter warming in northern Europe. Looking deeper into northern Europe, Seppä et al. (2009) presented a synthesis of the temperature variability in Scandinavia and the Baltic region from 36 individual pollenderived July mean and annual mean temperature reconstructions. They found evidence of a clear mid-Holocene Thermal Maximum 8000-4800 BP, with annual mean temperatures about $2^{\circ} \mathrm{C}$ above pre-industrial ones. For the area covered by the former Soviet Union and Mongolia, Tarasov et al. (1999) reconstructed the climate at $6000 \mathrm{BP}$ from pollen remains. They found that the winters in the whole region were about $2^{\circ} \mathrm{C}$ warmer than today and that the summers were warmer north of $60^{\circ} \mathrm{N}$ and in Mongolia, whereas in northern Kazakhstan and around the Black and Caspian Seas, summers were cooler than today. Cooler summers may also have existed in central Siberia.

Kaufman et al. (2004) investigated the spatio-temporal pattern of peak Holocene warmth in 140 sites across the Western Hemisphere of the Arctic. They found that summer temperatures during the mid-Holocene Thermal Maximum were $1.6 \pm 0.8^{\circ} \mathrm{C}$ higher than the average of the 20th century, but that peak Holocene warmth occurred much earlier in western Canada and Alaska than elsewhere. The peak warmth occurred latest in Labrador due to the lingering Laurentide Ice Sheet. Viau et al. (2006) reconstructed the millennial-scale July temperature variability in North America from pollen dis- 
tributions during the last 14000 years and found only small variability since the rapid $4-5^{\circ} \mathrm{C}$ warming of the deglaciation. Nevertheless, they reported a stable mid-Holocene Thermal Maximum 6000-3000 BP with a peak warming as late as c. 3200 BP. Viau et al. (2008) presented a January, July and annual pollen-derived temperature reconstruction for eastern Beringia and found a peak winter warming as early as $11000 \mathrm{BP}$ and maximum summer and annual temperatures from 8000-7000 BP with little long-term change during the last $\sim 6000$ years. Viau and Gajewski (2009) reconstructed the Holocene January and July temperature variations of boreal and low-Arctic Canada with pollen data. They found the clearest Holocene temperature maximum, both in summer and winter, in central Canada c. 12000-8000 BP. In northern Quebec, temperatures peaked around $8000 \mathrm{BP}$ and the mid-Holocene Thermal Maximum occurred, as in Kaufman et al. (2004), later and less pronounced along the Labrador coast.

There exist two important syntheses of sea surface temperature data covering the Holocene. Kim et al. (2004) investigated available Northern Hemisphere alkenone-derived sea-surface temperature records and demonstrated a Holocene cooling trend in the North Atlantic region but a warming trend in the North Pacific and Indian Ocean region. On lower latitudes at least, a midHolocene Thermal Maximum could only be seen in the North Atlantic region. Leduc et al. (2010) reviewed globally available alkenone- and foraminiferal $\mathrm{Mg} / \mathrm{Ca}$-derived sea surface temperature records for the Holocene. They found a cooling Holocene trend, and the existence of the mid-Holocene Thermal Maximum on high latitudes in both the Northern and Southern Hemisphere, but a warming trend in most tropical records. Though it should be noted the tropical records showed quite a heterogeneous pattern. For Africa, there are no quantitative large-scale temperature reconstructions but several reconstructions of annual precipitation exist. A model-data comparison by Peyron et al. (2006) showed that at 6000 BP Sahara-Sahel was 200-700 mm/year wetter than today but a longer dry season prevailed during the boreal winter near the equator. Wu et al. (2007) found that the climate was generally wetter in northern Africa at $6000 \mathrm{BP}$ and, moreover, that it was significantly warmer than today in southern and eastern Africa yet cooler in tropical Africa.

The IPCC report (Solomon et al., eds. 2007) was inconclusive whether at least parts of the mid-Holocene Thermal Maximum experienced globally higher temperatures than the present ones. According to IPCC (Solomon et al., eds. 2007) the "spatial coverage, temporal resolution and age control of available Holocene proxy data limit the ability to determine if there were multi-decadal periods of global warmth comparable to the last half of 20th century". A major problem for our understanding of the mid-Holocene Thermal Maximum is the dominance of proxy records sensitive to specific seasons (e.g. summer) and the limited number of records from lower latitudes. This lack of appropriate quantitative palaeotemperature data, especially for the Southern Hemisphere, together with the inability of state-of-the-art General Circulation Models and Energy Balance Models to simulate global mean annual temperatures higher than those of today, have thus led to the conclusion that the mid-Holocene Thermal Maximum was very likely not a globally synchronous event. Increasingly more data to better address this question are becoming available, but a more comprehensive assessment of the global spatio-temporal pattern of 
the mid-Holocene Thermal Maximum has yet to be done. Here, we present a review of quantitative palaeotemperature records in order to give tentative answers to the following two questions: (1) What do we presently know of the spatio-temporal pattern of the mid-Holocene Thermal Maximum from available palaeotemperature reconstructions? (2) Did any multi-centennial period of the mid-Holocene Thermal Maximum likely experience a substantially (i.e. more than $1^{\circ} \mathrm{C}$ ) higher annual mean temperature than the pre-industrial $(\sim 1750 \mathrm{AD})$ period according to available palaeotemperature reconstructions?

\section{Data and method}

Through a screening of the peer-reviewed literature for quantitative palaeotemperature reconstructions of annual mean air temperatures and annual mean sea-surface temperatures, 60 records with reasonably high temporal resolution covering the mid-Holocene to the pre-industrial period were selected for this study. In order to capture only annual changes in temperatures, all seasonal reconstructions were avoided. The temperature reconstructions were, when possible, obtained as digital data (either from http://www.ncdc. noaa.gov/paleo, http://www.pangaea.de or directly from the author) or otherwise digitized from the graphs appearing in the respective publications.

Essential information about each record is given in Table 1a-b: e.g., (1) name of the record, (2) exact latitude and longitude, (3) type of proxy, and (4) reference to the original publication where the record first appeared. The proxy records are presented in Table 1a-b in geographical order from north to south and the location of each record is shown on the map in Figure 1. For more detailed information about a specific record, the reader is referred to the respective reference. Out of the 60 records, 37 are terrestrial records and 23 are marine records. Of the terrestrial records, 14 are from northern high

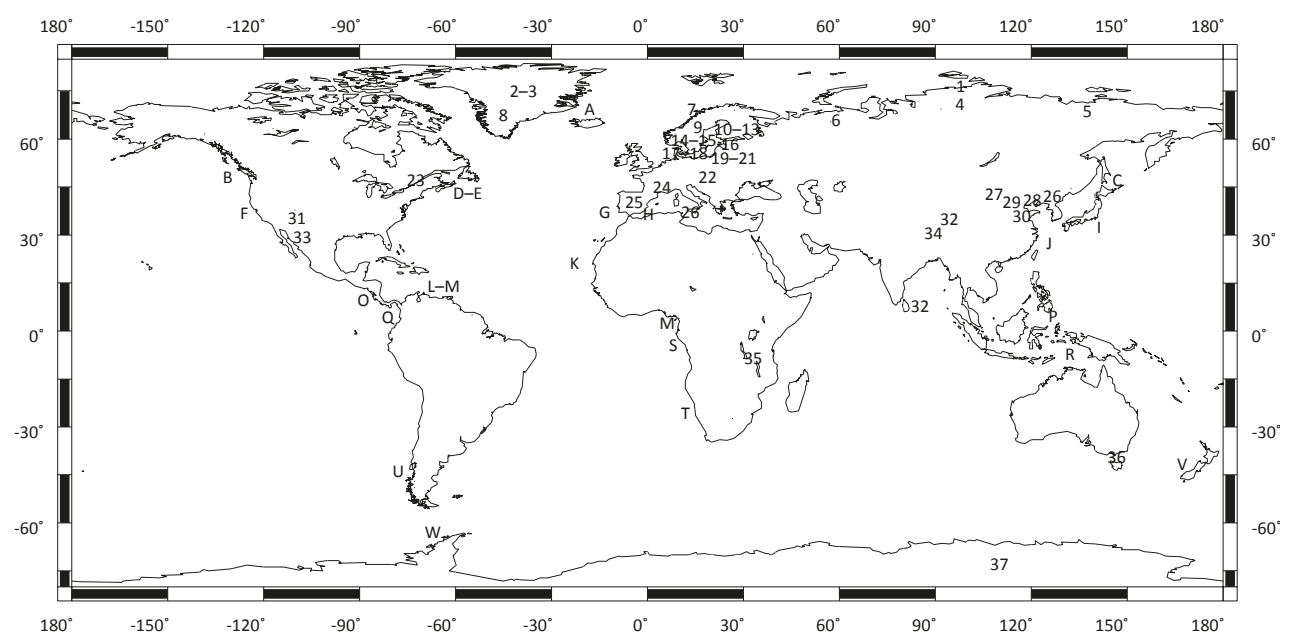

Fig. 1 - Map showing the location of the 60 palaeotemperature reconstructions presented in Table $1 \mathrm{a}-\mathrm{b}$ and Figure $2 \mathrm{a}-\mathrm{b}$ 
Table 1a - List of terrestrial temperature proxy records used for this study

\begin{tabular}{|c|c|c|c|c|}
\hline Proxy location & Latitude & Longitude & Proxy type & Reference \\
\hline 1. Levison-Lessing & $74.47^{\circ} \mathrm{N}$ & $98.63^{\circ} \mathrm{E}$ & Pollen $T_{\text {Ann }}$ & Andreev et al. 2003 \\
\hline 2. GRIP & $72.58^{\circ} \mathrm{N}$ & $38.50^{\circ} \mathrm{W}$ & Borehole $T_{\text {Ann }}$ & Dahl-Jensen et al. 1998 \\
\hline 3. GISP2 & $72.59^{\circ} \mathrm{N}$ & $38.46^{\circ} \mathrm{W}$ & Ice $T_{\mathrm{Ann}} \delta^{18} \mathrm{O}$ & Alley 2000 \\
\hline 4. Taymyr & $70.77^{\circ} \mathrm{N}$ & $99.13^{\circ} \mathrm{E}$ & Pollen $T_{\text {Ann }}$ & Andreev, Klimanov 2000 \\
\hline 5. Kazach'e & $70.77^{\circ} \mathrm{N}$ & $136.25^{\circ} \mathrm{E}$ & Pollen $T_{\text {Ann }}$ & $\begin{array}{l}\text { Andreev, Klimanov, } \\
\text { Sulerzhitsky } 2001\end{array}$ \\
\hline 6. Khaipudurskaya & $68^{\circ} \mathrm{N}$ & $60^{\circ} \mathrm{E}$ & Pollen $T_{\text {Ann }}$ & Andreev, Klimanov 2000 \\
\hline 7. Søylegrotta & $66.62^{\circ} \mathrm{N}$ & $13.68^{\circ} \mathrm{E}$ & Stalagmite $\delta^{18} \mathrm{O}$ & Lauritzen, Lundberg 1999 \\
\hline 8. Dye-3 & $65.18^{\circ} \mathrm{N}$ & $43.83^{\circ} \mathrm{W}$ & Borehole $T_{\text {Ann }}$ & $\begin{array}{l}\text { Dahl-Jensen, Morgan, } \\
\text { Elcheikh } 1998\end{array}$ \\
\hline 9. Klotjärnen & $61.82^{\circ} \mathrm{N}$ & $16.53^{\circ} \mathrm{E}$ & Pollen $T_{\text {Ann }}$ & Seppä et al. 2009 \\
\hline 10. Nautajärvi & $61.80^{\circ} \mathrm{N}$ & $24.68^{\circ} \mathrm{E}$ & Pollen $T_{\text {Ann }}$ & Ojala et al. 2008 \\
\hline 11. Laihalampi & $61.48^{\circ} \mathrm{N}$ & $26.07^{\circ} \mathrm{E}$ & Pollen $T_{\text {Ann }}$ & Heikkilä, Seppä 2003 \\
\hline 12. Kuivajärvi & $60.80^{\circ} \mathrm{N}$ & $23.80^{\circ} \mathrm{E}$ & Pollen $T_{\mathrm{Ann}}$ & Seppä et al. 2009 \\
\hline 13. Arapisto & $60.58^{\circ} \mathrm{N}$ & $24.08^{\circ} \mathrm{E}$ & Pollen $T_{\text {Ann }}$ & $\begin{array}{l}\text { Sarmaja-Korjonen, Seppä } \\
2007\end{array}$ \\
\hline 14. Gilltjärnen & $60.08^{\circ} \mathrm{N}$ & $15.83^{\circ} \mathrm{E}$ & Pollen $T_{\text {Ann }}$ & Antonsson et al. 2006 \\
\hline 15. Lilla Gloppsjön & $59.83^{\circ} \mathrm{N}$ & $14.58^{\circ} \mathrm{E}$ & Pollen $T_{\mathrm{Ann}}$ & Seppä et al. 2009 \\
\hline 16. Raigastvere & $58.58^{\circ} \mathrm{N}$ & $26.65^{\circ} \mathrm{E}$ & Pollen $T_{\mathrm{Ann}}$ & Seppä, Poska 2004 \\
\hline 17. Trehörningen & $58.55^{\circ} \mathrm{N}$ & $11.60^{\circ} \mathrm{E}$ & Pollen $T_{\text {Ann }}$ & Antonsson, Seppä 2007 \\
\hline 18. Flarken & $58.55^{\circ} \mathrm{N}$ & $13.67^{\circ} \mathrm{E}$ & Pollen $T_{\text {Ann }}$ & Seppä et al. 2005 \\
\hline 19. Lake Viitna & $59.45^{\circ} \mathrm{N}$ & $26.08^{\circ} \mathrm{E}$ & Pollen $T_{\mathrm{Ann}}$ & Seppä, Poska 2004 \\
\hline 20. Lake Ruila & $59.17^{\circ} \mathrm{N}$ & $24.43^{\circ} \mathrm{E}$ & Pollen $T_{\text {Ann }}$ & Seppä, Poska 2004 \\
\hline 21. Rouge & $57.73^{\circ} \mathrm{N}$ & $26.75^{\circ} \mathrm{E}$ & Pollen $T_{\text {Ann }}$ & Seppä et al. 2009 \\
\hline 22. NW Romania & $47.80^{\circ} \mathrm{N}$ & $23.52^{\circ} \mathrm{E}$ & Pollen $T_{\mathrm{Ann}}$ & Feurdean et al. 2008 \\
\hline 23. Quebec & $45.50^{\circ} \mathrm{N}$ & $73.67^{\circ} \mathrm{W}$ & Pollen $T_{\text {Ann }}$ & Muller et al. 2003 \\
\hline 24. Central Massif & $44.00^{\circ} \mathrm{N}$ & $4.00^{\circ} \mathrm{E}$ & Pollen $T_{\mathrm{Ann}}$ & Guiot 1987 \\
\hline 25. Quintanar & $42.03^{\circ} \mathrm{N}$ & $3.01^{\circ} \mathrm{W}$ & Pollen $T_{\mathrm{Ann}}$ & Peñalba et al. 1997 \\
\hline 26. Mt. Changbai & $41-42^{\circ} \mathrm{N}$ & $128^{\circ} \mathrm{E}$ & Pollen $T_{\mathrm{Ann}}$ & He et al. 2004 \\
\hline 27. Loess Plateau & $41-34^{\circ} \mathrm{N}$ & $101-114^{\circ} \mathrm{E}$ & Pollen $T_{\text {Ann }}$ & He et al. 2004 \\
\hline 28. S. Liaoning & $40^{\circ} \mathrm{N}$ & $122^{\circ} \mathrm{E}$ & Pollen $T_{\mathrm{Ann}}$ & He et al. 2004 \\
\hline 29. Beijing & $39.55^{\circ} \mathrm{N}$ & $116.25^{\circ} \mathrm{E}$ & Pollen $T_{\text {Ann }}$ & He et al. 2004 \\
\hline 30. East Hebei & $38^{\circ} \mathrm{N}$ & $117^{\circ} \mathrm{E}$ & Pollen $T_{\mathrm{Ann}}$ & He et al. 2004 \\
\hline 31. Montezuma Well & $34.65^{\circ} \mathrm{N}$ & $111.75^{\circ} \mathrm{W}$ & Pollen $T_{\text {Ann }}$ & Davis, Shafer 1992 \\
\hline 32. Qilian Mountains & $34.00^{\circ} \mathrm{N}$ & $97.20^{\circ} \mathrm{E}$ & Pollen $T_{\text {Ann }}$ & Herzschuh et al. 2009 \\
\hline 33. Sierra Madre & $29.00^{\circ} \mathrm{N}$ & $111.00^{\circ} \mathrm{W}$ & Pollen $T_{\mathrm{Ann}}$ & Ortega-Rosas et al. 2008 \\
\hline 34. Core HL1 & $29.00^{\circ} \mathrm{N}$ & $92^{\circ} \mathrm{E}$ & Pollen $T_{\text {Ann }}$ & Tang et al. 1999 \\
\hline 35. Lake Malawi & $9^{\circ} \mathrm{S}$ & $34^{\circ} \mathrm{E}$ & $\mathrm{TEX}_{86} T_{\mathrm{Ann}}$ & Powers et al. 2005 \\
\hline 36. Wairehu & $39.03^{\circ} \mathrm{S}$ & $175.70^{\circ} \mathrm{E}$ & Pollen $T_{\mathrm{Ann}}$ & Wilmshurst et al. 2007 \\
\hline 37. Law Dome & $68.4^{\circ} \mathrm{S}$ & $112.21^{\circ} \mathrm{E}$ & Borehole $T_{\text {Ann }}$ & Dahl-Jensen et al. 1999 \\
\hline
\end{tabular}


Table $1 \mathrm{~b}$ - List of marine temperature proxy records used for this study

\begin{tabular}{|c|c|c|c|c|}
\hline Proxy location & Latitude & Longitude & Proxy type & Reference \\
\hline A. JR51-GC35 & $67^{\circ} \mathrm{N}$ & $17.96^{\circ} \mathrm{W}$ & Alkenone $T_{\text {Ann }}$ SST & Bendle, Rosell-Melé 2007 \\
\hline B. JT96-09 & $48.54^{\circ} \mathrm{N}$ & $126.53^{\circ} \mathrm{W}$ & Alkenone $T_{\mathrm{Ann}} \mathrm{SST}$ & Kienast, McKay 2001 \\
\hline C. MD01-2412 & $44.53^{\circ} \mathrm{N}$ & $145.04^{\circ} \mathrm{E}$ & Alkenone $T_{\mathrm{Ann}} \mathrm{SST}$ & Harada et al. 2006 \\
\hline D. OCE326-GGC30 & $44.00^{\circ} \mathrm{N}$ & $63.00^{\circ} \mathrm{W}$ & Alkenone $T_{\mathrm{Ann}} \mathrm{SST}$ & Sachs 2007 \\
\hline E. OCE326-GGC26 & $43.48^{\circ} \mathrm{N}$ & $54.87^{\circ} \mathrm{W}$ & Alkenone $T_{\text {Ann }} \mathrm{SST}$ & Sachs 2007 \\
\hline F. ODP Site 1019 & $41.68^{\circ} \mathrm{N}$ & $124.93^{\circ} \mathrm{W}$ & Alkenone $T_{\mathrm{Ann}} \mathrm{SST}$ & Barron et al. 2003 \\
\hline G. Iberian Margin & $37.77^{\circ} \mathrm{N}$ & $10.18^{\circ} \mathrm{W}$ & Alkenone $T_{\mathrm{Ann}} \mathrm{SST}$ & Bard 2002 \\
\hline H. 161-977 & $36.03^{\circ} \mathrm{N}$ & $1.95^{\circ} \mathrm{W}$ & $\mathrm{Mg} / \mathrm{Ca} T_{\mathrm{Ann}} \mathrm{SST}$ & Martrat et al. 2004 \\
\hline I. Japan margin & $35.00^{\circ} \mathrm{N}$ & $141.00^{\circ} \mathrm{E}$ & Alkenone $T_{\mathrm{Ann}} \mathrm{SST}$ & Isono et al. 2009 \\
\hline J. Okinawa & $27.82^{\circ} \mathrm{N}$ & $126.98^{\circ} \mathrm{E}$ & $T_{\text {Ann }} \mathrm{SST}$ & Jian et al. 2000 \\
\hline K. ODP658C & $20.75^{\circ} \mathrm{N}$ & $18.58^{\circ} \mathrm{W}$ & $T_{\text {Ann }} \mathrm{SST}$ & deMenocal et al. 2000 \\
\hline L. M35003-4 & $12.08^{\circ} \mathrm{N}$ & $61.25^{\circ} \mathrm{W}$ & Alkenone $T_{\mathrm{Ann}} \mathrm{SST}$ & Rühlemann et al. 1999 \\
\hline M. Cariaco Basin & $10.77^{\circ} \mathrm{N}$ & $64.77^{\circ} \mathrm{W}$ & $\mathrm{Mg} / \mathrm{Ca} T_{\mathrm{Ann}} \mathrm{SST}$ & Lea et al. 2003 \\
\hline N. GeoB4905-4 & $9.39^{\circ} \mathrm{N}$ & $11.22^{\circ} \mathrm{E}$ & Alkenone $T_{\mathrm{Ann}} \mathrm{SST}$ & $\begin{array}{l}\text { Schefuß, Schouten, } \\
\text { Schneider } 2005\end{array}$ \\
\hline O. MD02-2529 & $8.20^{\circ} \mathrm{N}$ & $84.12^{\circ} \mathrm{W}$ & $\mathrm{Mg} / \mathrm{Ca} T_{\mathrm{Ann}} \mathrm{SST}$ & Leduc et al. 2007 \\
\hline P. MD81 & $6.18^{\circ} \mathrm{N}$ & $125.50^{\circ} \mathrm{E}$ & $\mathrm{Mg} / \mathrm{Ca} T_{\mathrm{Ann}} \mathrm{SST}$ & Stott et al. 2004 \\
\hline Q. KNR176-JPC32 & $4.85^{\circ} \mathrm{N}$ & $77.96^{\circ} \mathrm{W}$ & Alkenone $T_{\mathrm{Ann}} \mathrm{SST}$ & Pahnke et al. 2007 \\
\hline R. MD76 & $5.00^{\circ} \mathrm{S}$ & $133.26^{\circ} \mathrm{E}$ & $\mathrm{Mg} / \mathrm{Ca} T_{\mathrm{Ann}} \mathrm{SST}$ & Stott et al. 2004 \\
\hline S. GeoB6518-1 & $5.58^{\circ} \mathrm{S}$ & $9.39^{\circ} \mathrm{E}$ & Alkenone $T_{\mathrm{Ann}} \mathrm{SST}$ & Weldeab et al. 2007 \\
\hline T. ODP 1084B & $25.52^{\circ} \mathrm{S}$ & $13.03^{\circ} \mathrm{E}$ & $\mathrm{Mg} / \mathrm{Ca} T_{\mathrm{Ann}} \mathrm{SST}$ & $\begin{array}{l}\text { Farmer, Demenocal, } \\
\text { Marchitto } 2005\end{array}$ \\
\hline U. Off S. Chile & $41.00^{\circ} \mathrm{S}$ & $74.45^{\circ} \mathrm{W}$ & Alkenone $T_{\mathrm{Ann}} \mathrm{SST}$ & $\begin{array}{l}\text { Kaiser, Lamy, Hebbeln } \\
2005\end{array}$ \\
\hline V. SO136-011GC & $43.44^{\circ} \mathrm{S}$ & $167.85^{\circ} \mathrm{E}$ & Alkenone $T_{\mathrm{Ann}} \mathrm{SST}$ & Barrows et al. 2008 \\
\hline $\begin{array}{l}\text { W. W. Antarctic } \\
\text { Peninsula }\end{array}$ & $64.51^{\circ} \mathrm{S}$ & $64.12^{\circ} \mathrm{W}$ & $\mathrm{TEX}_{86} T_{\mathrm{Ann}} \mathrm{SST}$ & $\begin{array}{l}\text { Shevenell, Ingalls, } \\
\text { Domack } 2007\end{array}$ \\
\hline
\end{tabular}

latitudes $\left(90-60^{\circ} \mathrm{N}\right), 18$ from northern mid latitudes $\left(60-30^{\circ} \mathrm{N}\right), 2$ from northern low latitudes $\left(30-0^{\circ} \mathrm{N}\right)$, and 1 record each from the southern low $\left(0-30^{\circ} \mathrm{S}\right)$, mid $\left(30-60^{\circ} \mathrm{S}\right)$, and high latitudes $\left(60-90^{\circ} \mathrm{S}\right)$. Of the marine records, 1 is from northern high latitudes, 8 are from northern mid latitudes, 9 from northern low latitudes, 3 from southern low latitudes, 2 from southern mid latitudes, and 1 is from southern high latitudes. Altogether, 51 out of the 60 records are from the Northern Hemisphere, reflecting the relative lack of palaeotemperature data from the Southern Hemisphere.

Many potentially useful records unfortunately cannot be used in this study since they either represent seasonal temperatures or end before the pre-industrial period $\mathrm{AD} \sim 1750$. The latter is, for example, the case with most of the marine records presented in Kim et al. (2004) and Leduc et al. (2010) and also with some terrestrial records (e.g., Bordon et al. 2009; Jiang et al. 2006; Tierney et al. 2008). Most of the high-latitude records, including virtually 
all of those from Canada and Alaska, reflect summer temperatures and thus have not been useful here (for a review of the Arctic records, see Sundqvist et al. (2010)). Many other records also reflect seasonal temperatures (primarily summer and/or winter) and not annual temperatures, for instance Chase et al. (2008), Cheddadi et al. (1998), Heiri et al. (2003), Potito et al. (2006), and Tarasov et al. (2007). Only reconstructions from specific sites have been utilized and no regional reconstructions have been considered here. Hence, the data used for instance in Davis et al. (2003), Nakagawa et al. (2002), Viau et al. (2008), and Viau, Gajewski (2009) cannot be used here since they are not published as site-specific reconstructions.

The review of the spatio-temporal pattern of the mid-Holocene Thermal Maximum is achieved by assessing the coherency between the records of multicentennial periods during the last $10 \mathrm{ka} \mathrm{BP}$ with annual mean temperatures exceeding three different threshold values: (1) at least $1^{\circ} \mathrm{C}$ above pre-industrial ( 1750 AD) values, (2) at least $2^{\circ} \mathrm{C}$ above pre-industrial values, and (3) at least $1^{\circ} \mathrm{C}$ below pre-industrial values. Periods with temperatures that diverge less than $1^{\circ} \mathrm{C}$ from the pre-industrial temperatures will be considered "equal" to them. The results are visually presented in Figure 2. Low temporal resolution and uncertain dating of most of the reconstructions necessarily limit our assessment to warm and cold periods lasting several centuries. Hence, we are only concerned here with the temperature evolution over longer time-scales.

\section{Results}

As the graphical presentation in Figures $2 \mathrm{a}-\mathrm{b}$ and $3 \mathrm{a}-\mathrm{b}$ show, both hemispheres experienced mid-Holocene temperatures above pre-industrial ( $1750 \mathrm{AD})$ values during several millennia on most locations where data are available. The larger amount of data makes this result more robust for the Northern Hemisphere than for the Southern Hemisphere. The 60 reviewed reconstructions suggest that the mid-Holocene Thermal Maximum culminated c. 8-4 ka BP, with the warmest temperatures occurring c. 6-5 ka BP (Figure $3 \mathrm{a}-\mathrm{b})$. This is in line with what was reported by Klimenko, Klimanov and Fedorov (1996). The onset of the Neoglaciation seems to occur c. 4-3 ka BP. In some records, mainly but not exclusively from the high northern latitudes, a new multi-centennial period of temperatures exceeding those of the pre-industrial ( 1750 AD) period by more than $1^{\circ} \mathrm{C}$ seems to have occurred during the Medieval Warm Period (c. 800-1300 AD; see, e.g., Bradley et al. 2001, 2003; Broecker 2001; Esper, Frank 2009; Ljungqvist 2009). This brief interruption of the Neoglaciation was followed by the Little Ice Age (c. 1300-1900; see, e.g., Grove 1988; Matthews, Briffa 2005; Wanner et al. 2008), which the reconstructions suggest was the coldest period since at least c. 8 ka BP. Shorter periods of colder climate, notably the 8.2 ka BP event (Alley, Ágústsdóttir 2005), are not visible in Figures $2 \mathrm{a}-\mathrm{b}$ and $3 \mathrm{a}-\mathrm{b}$ due to the low temporal resolution and uncertain age control for most of the records. Nor have the much discussed quasi-cyclical c. $1470 \pm 500$ year climate oscillations known as the Bond Cycles, first observed in the North Atlantic region but recently also elsewhere, been clearly detected in the reconstructions (Wanner et al. 2008; Wanner, Bütikofer 2008). The reason behind this could partly be uncertain dating, but also that at 
a)

Proxy record

1. Levison-Lessing

2. GRIP

3. GISP2

4. Taymyr

5. Kazach'e

6. Khaipudurskaya

7. Søylegrotta

8. Dye-3

9. Klotjärnen

10. Nautajärvi

11. Kuivajärvi

12. Laihalampi

13. Arapisto

14. Gilltjärnen

15. Lilla Gloppsjön

16. Raigastvere

17. Trehörningen

18. Flarken

19. Lake Viitna

20. Lake Ruila

21. Rouge

22. NW Romania

23. Quebec

24. Central Massif

25. Quintanar

26. Mt. Changbai

27. Loess Plateau

28. S. Liaoning

29. Beijing

30. East Hebei

31. Montezuma Well

32. Qilian Mountains

33. Sierra Madre

34. Core HL1

35. Lake Malawi

36. Wairehu

37. Law Dome
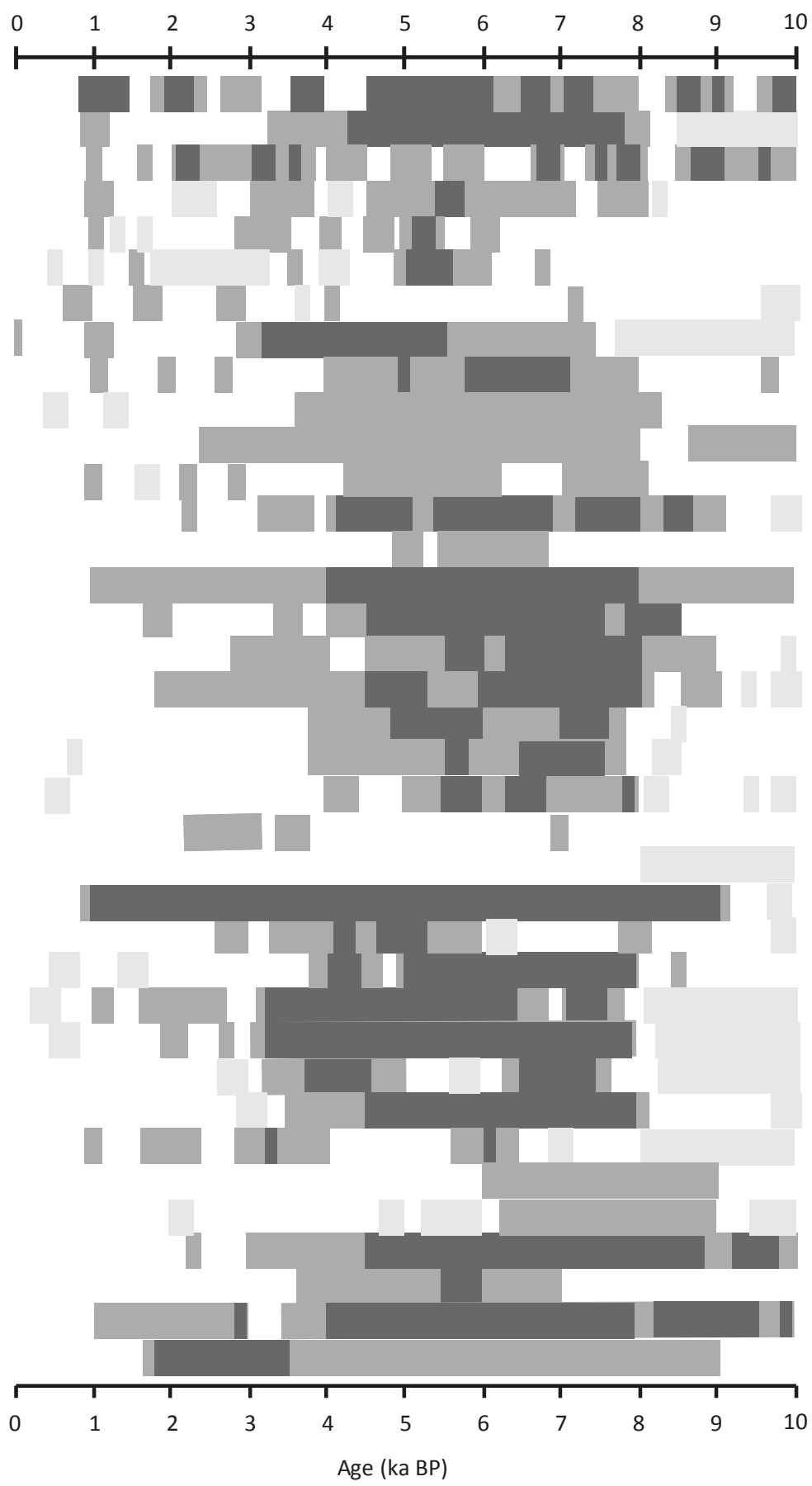
b)

Proxy record

A. JR51-GC35

B. JT96-09

C. MD01-2412

D. OCE326-GGC30

E. OCE326-GGC26

F. ODP Site 1019

G. Iberian Margin

H. 161-977

I. Japan margin

J. Okinawa

K. ODP658C

L. M35003-4

M. Cariaco Basin

N. GeoB4905-4

O. MD02-2529

P. MD81

Q. KNR176-JPC32

R. MD76

S. GeoB6518-1

T. ODP 1084B

U. Off S. Chile

V. S0136-011GC W. W. Antarctic
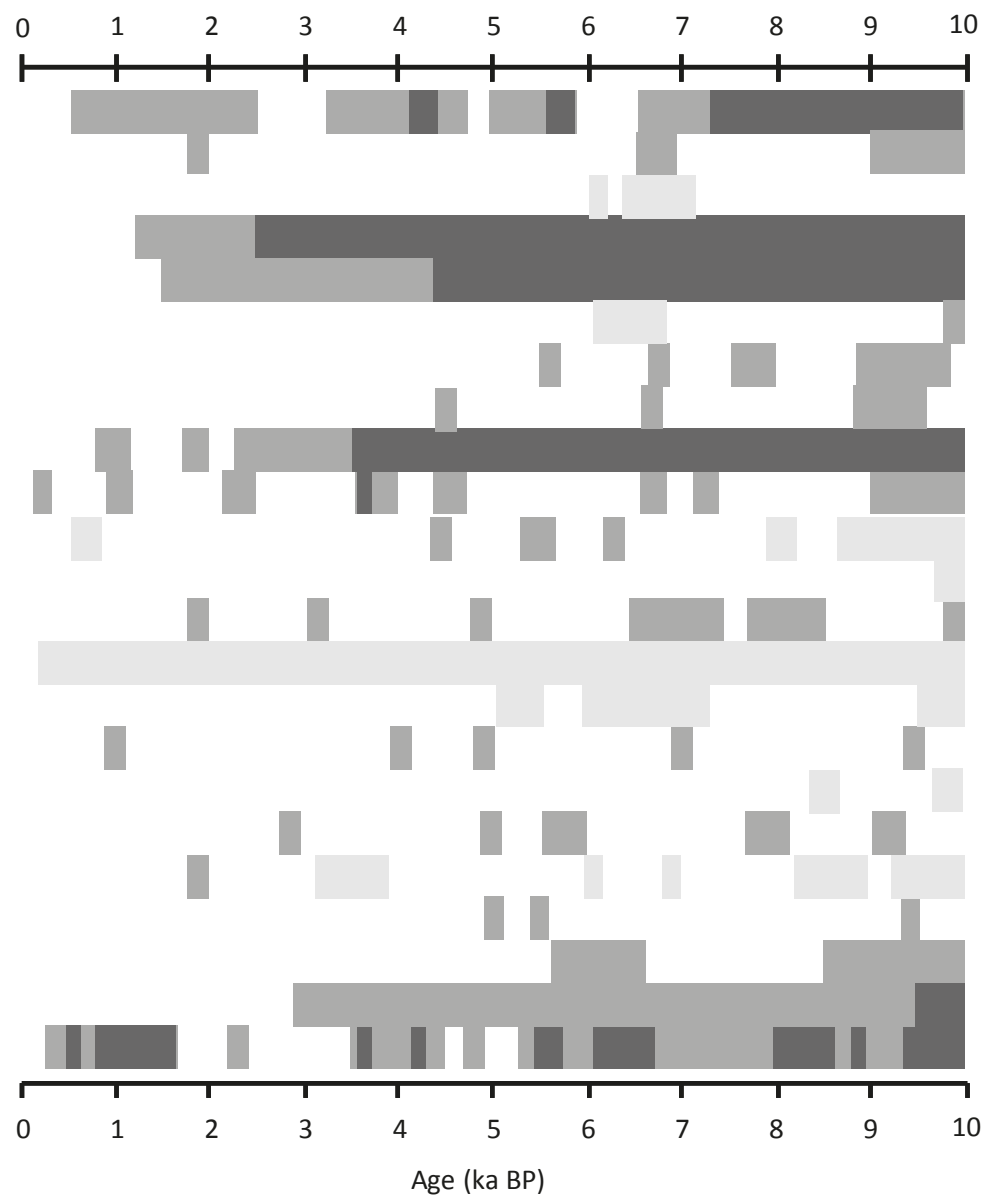

Fig. 2 - Periods marked in dark grey: at least $2^{\circ} \mathrm{C}$ above pre-industrial temperatures. Periods marked in grey: at least $1^{\circ} \mathrm{C}$ above pre-industrial temperatures. Periods marked in light grey: at least $1^{\circ} \mathrm{C}$ below pre-industrial values. Periods with temperatures that diverge less than $1^{\circ} \mathrm{C}$ from the pre-industrial temperatures are not shown.

most locations many of the Bond cycles probably had an amplitude of less than the threshold value of $1^{\circ} \mathrm{C}$ used here.

Perhaps surprisingly, no distinct spatio-temporal pattern of the midHolocene Thermal Maximum is noticeable in the 60 geographically widely scattered reconstructions (Figure 2a-b). Differences between reconstructions from the same region actually seem to be about as big as those between different hemispheres, regions or latitudes. Previous research has indicated that high latitudes in the Southern Hemisphere experienced a mid-Holocene Thermal Maximum earlier than the Northern Hemisphere (Masson et al. 2000; Williams et al. 2004). This assumption is not supported by the data presented in Figures $2 a-b$ and $3 a-b$. Instead, both hemispheres seem to have experienced the mid-Holocene Thermal Maximum at about the same time, in line with the results of a recent study by Shakun and Carlson (2010). Keeping 

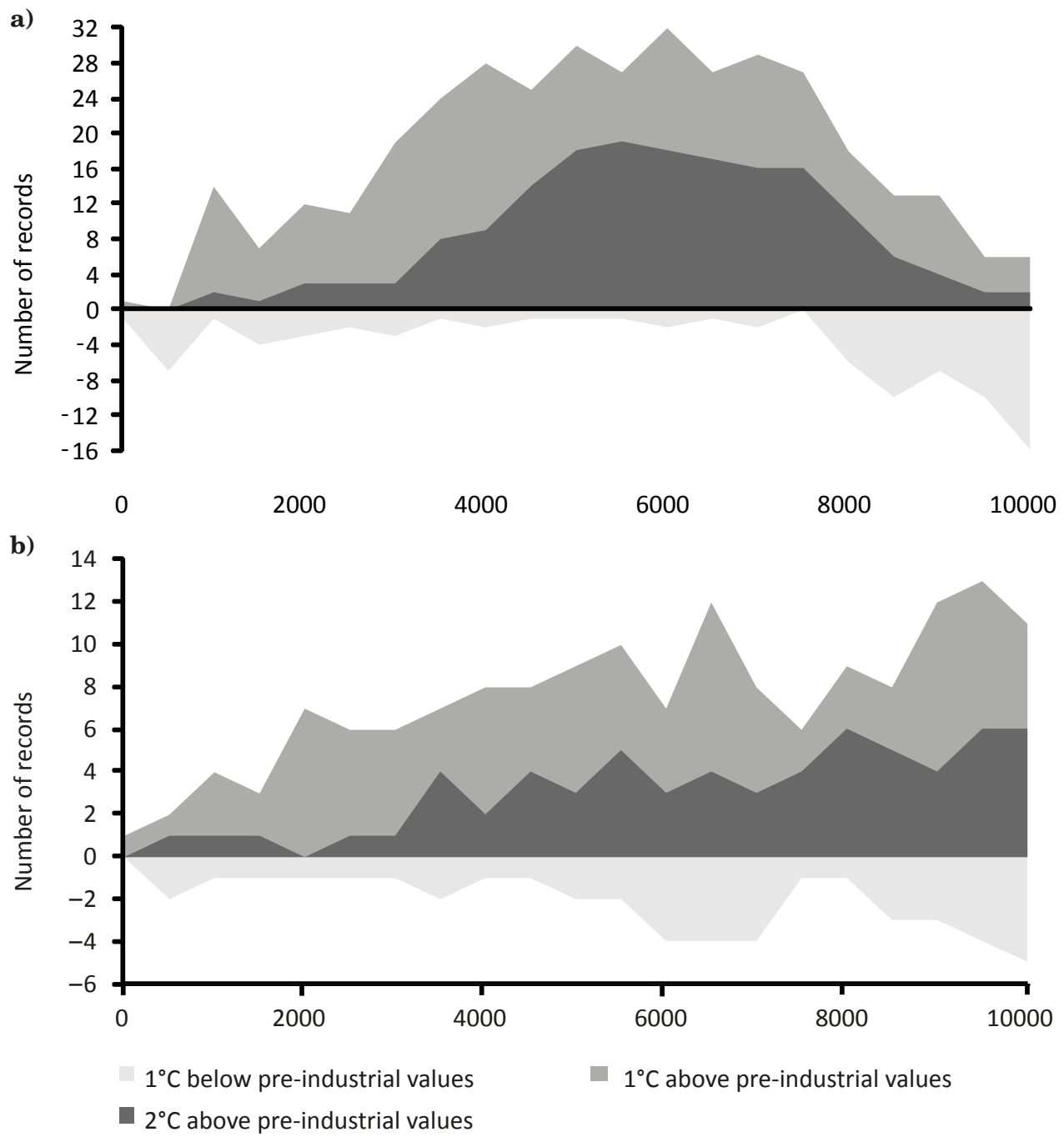

Fig. 3 - Number of records during different periods being at least $2^{\circ} \mathrm{C}$ above, at least $1^{\circ} \mathrm{C}$ above or at least $1^{\circ} \mathrm{C}$ below pre-industrial values

in mind the limited data available from the Southern Hemisphere, we can conclude that the amplitude of this warming seems to have been equivalent in both hemispheres and smallest in the tropical regions.

\section{Discussion}

As highlighted in the IPCC report (Solomon et al., eds. 2007), our knowledge of the global or hemispheric temperature evolution during the Holocene period is still very inadequate. This is a serious shortcoming concerning our ability to predict the future climate and the relative influence of different natural and 
anthropogenic forcings. Our review of the timing of periods during mid- and late-Holocene with annual mean temperatures $1^{\circ} \mathrm{C}$ and $2^{\circ} \mathrm{C}$ above those in the pre-industrial $(\sim 1750 \mathrm{AD})$ period indicates that the mid-Holocene Thermal Maximum was more temporally coherent around the globe than generally thought. This in turn implies that the earth during the Holocene period perhaps experienced larger long-term changes in global mean temperature than usually acknowledged. One notable feature observed in the 60 records discussed here is that there is an earlier maximum warming in many of the marine records compared to the terrestrial records. It ought to be an important question for subsequent research to investigate if the mid-Holocene Thermal Maximum occurred earlier in oceans than on land or if this is just an artefact of insufficient data quality or of uneven geographical coverage.

This study represents the first systematic attempt to collect a larger number of globally distributed proxy records of annual mean temperature from different archives and synthesize their spatial-temporal information. Previous studies, tracking the mid-Holocene Thermal Maximum, have either been more restricted geographically or limited to a single type of proxy archive. The most important gain with this study is to bring together the information from 60 site-specific annual mean temperature reconstructions in order to get an improved overview of what currently available data show. Our main result is that site-specific reconstructions of annual mean temperature tend to indicate a more spatially coherent warm pattern during the mid-Holocene than usually thought.

State-of-the-art General Circulation Models and Energy Balance Models are unable to simulate a significant change in the global mean temperature due to changes in orbital forcing, or to any other changes in natural forcing known to have occurred during the Holocene (Hewitt, Mitchell 1998; Ganopolski et al. 1998; Kitoh, Murakami 2002; Masson-Delmotte et al. 2005; Wanner et al. 2008). On the other hand, composites of temperature measurements from boreholes drilled into the Earth crust indicate a mid-Holocene Thermal Maximum with temperatures more than $2^{\circ} \mathrm{C}$ warmer than during the pre-industrial period (Huang, Pollack, Shen 2008). If the mid-Holocene Thermal Maximum indeed represented a considerable global warming, it presupposes strong positive feedbacks in the climate system that are still poorly understood.

The spatio-temporal pattern of the Mid-Holocene Thermal Maximum, evident from Figures $2 \mathrm{a}-\mathrm{b}$ and $3 \mathrm{a}-\mathrm{b}$, can briefly be discussed in the light of glaciological evidence. Beginning with the northern high latitudes, glaciers were much reduced on Frans Josef Land and Svalbard 10-3 ka BP (Svendsen, Mangerud 1997; Lubinski, Forman, Miller 1999). Local coastal glaciers on Greenland were at approximately the same time reduced in size (Kelly, Lowell 2009 ) and Icelandic glaciers were significantly smaller than today $\sim 8-4.5 \mathrm{ka}$ BP (Geirsdóttir et al. 2009). The evidence is somewhat more inconclusive from the Canadian Arctic Archipelago but Briner, Davis, Miller (2009) have shown evidence of reduced glaciers on Baffin Island 7.5-4 ka BP. Scandinavian mountain glaciers were absent or much reduced $\sim 9.5-3$ ka BP (Nesje 2009), and although the picture from Alaska is somewhat less clear, glaciers in southern Alaska were smaller than today before the Neoglaciation 4.5-4.0 ka BP (Barclay, Wiles, Calkin 2009). Moving to the northern mid-latitudes, Ivy-Ochs et al. (2009) concluded that glaciers in the European Alps 10.5-3.3 ka BP were 
smaller than they are today. A similar glacial history for the Canadian Cordillera was found by Menounos et al. (2009). Röthlisberger and Geyh (1985) concluded that the glaciers in the Himalaya and Karakoram ranges of Asia were smaller than today $\sim 7-4.5 \mathrm{ka}$ BP. Evidence is sparser for the tropics and the Southern Hemisphere but Rodbell, Smith, Mark (2009) found that few, if any, significant glacier advances occurred during the Holocene in the Andes prior to the Neoglaciation $4.5 \mathrm{ka}$ BP. Glaciological data from Antarctica and the Sub-antarctic Islands indicate a generally reduced mid-Holocene glacier extent but also point to glacier advances $~ 8-7 \mathrm{ka} \mathrm{BP}$ and $~ 5.5-4.5 \mathrm{BP}$ (Hall 2009). All in all, the glaciological evidence seems to broadly support the spatio-temporal pattern of periods with temperatures at least $1^{\circ} \mathrm{C}$ and $2^{\circ} \mathrm{C}$, respectively, above the pre-industrial level.

To this date, there exist no direct quantitative temperature reconstructions on a global scale longer than 2000 years, except borehole temperature measurements (Solomon et al., eds. 2007; NRC 2006). To accomplish such reconstructions, preferably with quantitative error bars, ought to be an urgent challenge for the palaeoclimatological community now that sufficient data are becoming increasingly available to make such reconstructions feasible. However, in order to better understand the spatio-temporal pattern of the mid-Holocene Thermal Maximum, we have need of more quantitative temperature reconstructions from regions where little palaeoclimatological work has been done so far (e.g., Africa, Australia, and South America). It is also important to make more of existing and future data digitally available in publicly accessible and searchable databases such as http://www.ncdc.noaa.gov/paleo and http://www.pangaea. de. As it is now, much valuable palaeoclimatological data is unavailable for use in multi-proxy syntheses and for comparisons of various kinds.

\section{Conclusions}

Our assessment of 60 annual mean temperature reconstructions from different locations around the globe indicate a more coherent mid-Holocene Thermal Maximum than hitherto reported. Focusing on the first question posed in the introduction, we can from the palaeotemperature reconstructions presented here conclude, in line with Solomon et al., eds. (2007), that the absolute peak temperatures during the mid-Holocene Thermal Maximum likely occurred at different times in different regions. Moreover, even proxy records from the same regions show a different temporal pattern of maximum warming, which limits our possibility to investigate to what degree the warming was synchronous. Although the early part of the mid-Holocene (10-8 ka BP) exhibits a very heterogeneous pattern, with some locations showing temperatures much higher than the pre-industrial ( $1750 \mathrm{AD})$ period and others showing much lower temperatures, the latter part of the mid-Holocene (7-4 ka BP) shows more homogeneously higher temperatures than those of the pre-industrial period except for perhaps in the tropical region (see Figure 2a-b and Figure $3 \mathrm{a}-\mathrm{b})$.

This leads us to the second question posed in the introduction, namely whether there were periods during the mid-Holocene that likely experienced more than $1^{\circ} \mathrm{C}$ higher annual mean temperature than in the pre-industrial pe- 
riod. We find no indications that support the IPCC (Solomon et al., eds. 2007) conclusion that global annual mid-Holocene temperatures were not warmer than today or that the earth during the mid-Holocene Thermal Maximum only experienced increased temperatures during the summer season and on higher latitudes in the Northern Hemisphere.

On the contrary, our survey suggests that annual mean temperatures were higher in large areas of the globe in both hemispheres, although the temperature increase was amplified on high latitudes, especially in the Northern Hemisphere. The warming is less clear in some locations at low latitudes, where a few records show a cooling during some intervals of the mid-Holocene. Our conclusions are, arguably, somewhat weakened by the low resolution of much of the data and the considerable dating uncertainties of many of the records as well as the lack of data from some regions (e.g., Southern Europe), shown in other studies (e.g., Bartlein et al. 2011), likely to have had lower temperatures during the mid-Holocene. We would cautiously suggest, in agreement with borehole temperature composites (Huang, Pollack, Shen 2008), that it is very likely that the earth experienced multi-centennial periods during the Holocene with global mean temperatures at least $1^{\circ} \mathrm{C}$ above the pre-industrial temperatures and possibly even more. However, more reliable conclusions in this matter cannot be reached until more data have become available for low latitudes and the Southern Hemisphere.

\section{References:}

ALLEY, R.B. (2000): The Younger Dryas cold interval as viewed from Central Greenland. Quaternary Science Reviews, 19, pp. 213-226.

ALLEY, R.B., ÁGÚSTSDÓTTIR, A.M. (2005): The 8k event: cause and consequences of a major Holocene abrupt climate change. Quaternary Science Reviews, 24, pp. 1123-1149.

ANDREEV, A.A., KLIMANOV, V.A. (2000): Quantitative Holocene climatic reconstruction from Arctic Russia. Journal of Paleolimnology, 24, pp. 81-91.

ANDREEV, A.A., KLIMANOV, V.A., SULERZHITSKY, L.D. (2001): Vegetation and climate history of the Yana River lowland, Russia, during the last 6400 yr. Quaternary Science Reviews, 20, pp. 259-266.

ANDREEV, A.A., TARASOV, P.E., SIEGERT, C., EBEL, T., KLIMANOV, V.A., MELLES, M., BOBROV, A., DEREVIAGIN, A.Y., LUBINSKI, D., HUBBERTEN, H.-W. (2003): Late Pleistocene vegetation and climate on the northern Taymyr Peninsula, Arctic Russia. Boreas, 32, pp. 484-505.

ANTONSSON, K., BROOKS, S.J., SEPPÄ, H., TELFORD, R.J., BIRKS, H.J.B. (2006): Quantitative palaeotemperature records inferred from fossil chironomid and pollen assemblages from Lake Gilltjärnen, northern central Sweden. Journal of Quaternary Science, 21, pp. 831-841.

ANTONSSON, K., SEPPÄ, H. (2007): Holocene temperatures in Bohuslän, Southwestern Sweden: a quantitative reconstruction from fossil pollen data. Boreas, 36, pp. 400-410.

BARCLAY, D.J., WILES, G.C., CALKIN, P.E. (2009): Holocene glacier fluctuations in Alaska. Quaternary Science Reviews, 28, pp. 2034-2048.

BARD, E. (2002): Climate shock: abrupt climate changes over millennial time scales. Physics Today, 55, pp. 32-38.

BARRON, J.A., HEUSSER, L., HERBERT, T., LYLE, M. (2003): High-resolution climate evolution of coastal northern California during the past 16,000 years. Paleoceanography, 18, p. 1020, doi: 10.1029/2002PA000768.

BARROWS, T.T., LEHMAN, S.J., FIFIELD, L.K., and DE DECKKER, P. (2008): Absence of cooling in New Zealand and the adjacent ocean during the Younger Dryas chronozone. Science, 318, pp. 86-89. 
BARTLEIN, P.J., HARRISON, S.P., BREWER, S., CONNOR, S., DAVIS, B.A.S., GAJEWSKI, K., GUIOT, J., HARRISON-PRENTICE, T.I., HENDERSON, A., PEYRON, O., PRENTICE, I.C., SCHOLZE, M., SEPPÄ, H., SHUMAN, B., SUGITA, S., THOMPSON, R.S., VIAU, A.E., WILLIAMS, J., WU, H. (2011): Pollen-based continental climate reconstructions at 6 and $21 \mathrm{ka}$ : a global synthesis. Climate Dynamics, in press.

BENDLE, J.A.P., ROSELL-MELÉ, A. (2007): High-resolution alkenone sea surface temperature variability on the North Icelandic Shelf: implications for Nordic Seas palaeoclimatic development during the Holocene. The Holocene, 17, pp. 9-24.

BERGER, A. LOUTRE, M.F. (1991): Insolation values for the climate of the last 10 million years. Quaternary Science Reviews, 10, pp. 297-317.

BORDON, A., PEYRON, O., LÉZINE, A.-M., BREWER, S., FOUACHE, E. (2009): Pollen-inferred Late-Glacial and Holocene climate in southern Balkans (Lake Maliq). Quaternary International, 200, pp. 19-30.

BRADLEY, R.S., BRIFFA, K.R., CROWLEY, T.J., HUGHES, M.K., JONES, P.D., MANN, M.E. (2001): The scope of medieval warming. Science, 292, pp. 2011-2012.

BRADLEY, R.S., HUGHES, M.K., DIAZ, H.F. (2003): Climate in medieval time. Science, 302, pp. 404-405.

BRINER, J.P., DAVIS, P.T., MILLER, G.H. (2009): Latest Pleistocene and Holocene glaciation of Baffin Island, Arctic Canada: key patterns and chronologies. Quaternary Science Reviews, 28, pp. 2075-2087.

BROECKER, W.S. (2001): Was the Medieval Warm Period global?. Science, 291, pp. 1497-1499.

CHASE, M., BLESKIE, C., WALKER, I.R., GAVIN, D.G., HU, F.S. (2008): Midge-inferred Holocene summer temperatures in Southeastern British Columbia, Canada. Palaeogeography, Palaeoclimatology, Palaeoecology, 257, pp. 244-259.

CHEDDADI, R., YU, G., GUIOT, J., HARRISON, S.P., PRENTICE, I.C. (1997): The climate of Europe 6000 years ago. Climate Dynamics, 13, pp. 1-9.

CHEDDADI, R., LAMB, H.F., GUIOT, J., VAN DER KAARS, S. (1998): Holocene climatic change in Morocco: a quantitative reconstruction from pollen data. Climate Dynamics, 14 , pp. 883-890.

DAHL-JENSEN, D., MORGAN, V.I., AND ELCHEIKH, A. (1999): Monte Carlo inverse modelling of the Law Dome (Antarctica) temperature profile. Annals of Glaciology, 29, pp. $145-150$.

DAHL-JENSEN, D., MOSEGAARD, K., GUNDESTRUP, N., CLOW, G.D., JOHNSEN, S.J., HANSEN, A.W., BALLING, N. (1998): Past temperatures directly from the Greenland Ice Sheet. Science, 282, pp. 268-271.

DAVIS, B.A.S., BREWER, S., STEVENSON, A.C., GUIOT, J., DATA CONTRIBUTORS (2003): The temperature of Europe during the Holocene reconstructed from pollen data. Quaternary Science Reviews, 22, pp. 1701-1716.

DAVIS, O.K., SHAFER, D.S. (1992): A Holocene climatic record for the Sonoran Desert from pollen analysis of Montezuma Well, Arizona, USA. Palaeogeography, Palaeoclimatology, Palaeoecology, 92, pp. 107-119.

DEMENOCAL, P.B., ORTIZ, J., GUILDERSON, T., SARNTHEIN, M. (2000): Coherent High- and Low-Latitude Climate Variability During the Holocene Warm Period. Science, 288 , pp. 2198-2202.

ESPER, J., FRANK, D.C. (2009): IPCC on heterogeneous Medieval Warm Period. Climatic Change 94, pp. 267-273.

FARMER, E.C., DEMENOCAL, P.B., MARCHITTO, T.M. (2005): Holocene and deglacial ocean temperature variability in the Benguela upwelling region: Implications for lowlatitude atmospheric circulation. Paleoceanography, 20, PA2018.

FEURDEAN, A., KLOTZ, S., MOSBRUGGER, V., WOHLFARTH, B. (2008): Pollen-based quantitative reconstructions of Holocene climate variability in NW Romania. Palaeogeography, Palaeoclimatology, Palaeoecology, 260, pp. 494-504.

GANOPOLSKI, A., KUBATZKI, C., CLAUSSEN, M., BROVKIN, V., PETOUKHOV, V. (1998): The influence of vegetation-atmosphere-ocean interaction on climate during the mid-Holocene. Science, 280, pp. 1916-1919.

GEIRSDÓTTIR, A., MILLER, G.H., AXFORD, Y., ÓLAFSDÓTTIR, S. (2009): Holocene and latest Pleistocene climate and glacier fluctuations in Iceland. Quaternary Science Reviews, 28, pp. 2107-2118. 
GROVE, J.M. (1988). The Little Ice Age. London. Methuen, 498 pp.

GUIOT, J. (1987): Late quaternary climatic change in France estimated from multivariate pollen time series. Quaternary Research, 28, pp. 100-118.

HALL, B. (2009): Holocene glacial history of Antarctica and the subantarctic islands. Quaternary Science Reviews, 28, pp. 2213-2230.

HARADA, N., AHAGON, N., SAKAMOTO, T., UCHIDA, M., IKEHARA, M., SHIBATA, Y. (2006): Rapid flucatuation of alkenone temperature in the southwestern Okhotsk Sea during the past $120 \mathrm{ky}$. Global and Planetary Change, 53, pp. 29-46.

HE, Y., THEAKSTONE, W.H., ZHANG. Z., ZHANG. D., YAO. T., CHEN. T., SHEN, Y., PANG, H. (2004): Asynchronous Holocene climatic change across China. Quaternary Research, 61, pp. 52-63.

HEIKKILÄ, M., SEPPÄ, H. (2003): A 11000 yr palaeotemperature reconstruction from the southern boreal zone in Finland, Quaternary Science Reviews, 22, pp. 541-554.

HEIRI, O., LOTTER, A.F., HAUSMANN, S., KIENAST, F. (2003): A chironomid-based Holocene summer air temperature reconstruction from the Swiss Alps. The Holocene, 13, pp. 477-484.

HERZSCHUH, U., KRAMER, A., MISCHKE, S., ZHANG, C. (2009): Quantitative climate and vegetation trends since the late glacial on the northeastern Tibetan Plateau deduced from Koucha Lake pollen spectra. Quaternary Research, 71, pp. 162-171.

HEWITT, C.D. MITCHELL, J.F.B. (1998): A Fully Coupled GCM Simulation of the Climate of the Mid-Holocene. Geophysical Research Letters, 25, pp. 361-364.

HUANG, S.P., POLLACK, H.N., SHEN, P.-Y. (2008): A late Quaternary climate reconstruction based on borehole heat flux data, borehole temperature data, and the instrumental record. Geophysical Research Letters, 35, L13703.

ISONO, D., YAMAMOTO, M., IRINO, T., OBA, T., MURAYAMA, M., NAKAMURA, T., KAWAHATA, K. (2009): The 1,500-year climate oscillation in the mid-latitude North Pacific during the Holocene. Geology, 37, pp. 591-594.

IVY-OCHS, S., KERSCHNER, H., MAISCH, M., CHRISTL, M., KUBIK, P.W., SCHLUCHTER, C. (2009): Latest Pleistocene and Holocene glacier variations in the European Alps. Quaternary Science Reviews, 28, pp. 2137-2149.

JIAN, Z., WANG, P., SAITO, Y., WANG, J., PFL AUMANN, U., OBA, T., CHENG, X. (2000): Holocene variability of the Kuroshio Current in the Okinawa Trough, northwestern Pacific Ocean. Earth and Planetary Science Letters, 184, pp. 305-319.

JIANG, W., GUO, Z., SUN, X., WU, H., CHU, G., YUAN, B., HATTÉ, C., GUIOT, J. (2006): Reconstruction of climate and vegetation changes of Lake Bayanchagan (Inner Mongolia): Holocene variability of the East Asian monsoon. Quaternary Research, 65, pp. 411-420.

KAISER, J., LAMY. F., HEBBELN, D. (2005): A 70-kyr sea surface temperature record off southern Chile (Ocean Drilling Program Site 1233). Paleoceanography, 20, PA4009. doi:10.1029/2004PA001146.

KAUFMAN, D.S., AGER, T.A., ANDERSON, N.J., ANDERSON, P.M., ANDREWS, J.T., BARTELEIN, P.J., BURBAKER, L.B., COATS, L.L., CWYNAR, L.C., DUVAL, M.L., DYKE, A.S., EDWARDS, M.E., EISER, W.R., GAJEWSKI, K., GEISODOTTIR, A., HU, F.S., JENNINGS, A.E., KAPLAN, M.R., KEWIN, M.W., LOZHKIN, A.V., MACDONALD, G.M., MILLER, G.H., MOCK, C.J., OSWALD, W.W., OTTO-BLISNER, B.L., PORINCHU, D.F., RÜHLAND, K., SMOL, J.P., STEIG, E.J., WOLFE, B.B. (2004): Holocene thermal maximum in the western Arctic $\left(0-180^{\circ} \mathrm{W}\right)$. Quaternary Science Reviews, 23, pp. 529-560.

KELLY M.A., LOWELL, T.V. (2009): Fluctuations of local glaciers in Greenland during latest Pleistocene and Holocene time. Quaternary Science Reviews, 28, pp. 2088-2106.

KIENAST, S.S., MCKAY, J.L. (2001): Sea surface temperatures in the subarctic Northeast Pacific reflect millennial-scale climate oscillations during the last 16 kyrs. Geophysical Research Letters, 28, pp. 1563-1566.

KIM, J.-H., RIMBU, N., LORENZ, S.J., LOHMANN, G., NAM, S.-I., SCHOUTEN, S., RÜHLEMANN, C., SCHNEIDER, R.R. (2004): North Pacific and North Atlantic sea surface temperature variability during the Holocene. Quaternary Science Reviews, 23, pp. 2141-2154.

KITOH, A., MURAKAMI, S. (2002): Pacific climate at the Mid-Holocene and the Last Glacial Maximum simulated by a coupled ocean-atmosphere GCM. Paleoceanography, 17, p. 1047. doi:10.1029/2001PA000724. 
KLIMENKO, V.V., KLIMANOV, V.A., FEDOROV, M.V. (1996): The history of the mean temperature of the northern hemisphere over the last 11000 years. Transactions of the Russian Academy of Sciences: Earth Science Sections, 348, pp. 626-629.

LAMB, H.H. (1977): Climate: Present, past and future 2. Climatic history and the future. London. Methuen, $835 \mathrm{pp}$.

LAURITZEN, S.-E., LUNDBERG, J. (1999): Calibration of the speleothem delta function: an absolute temperature record for the Holocene in northern Norway. The Holocene, 9, pp. 659-669.

LEA, D.W., PAK, D.K., PETERSON, L.C., HUGHEN, K.A. (2003): Synchroneity of tropical and high-latitude Atlantic temperatures over the last glacial termination. Science, 301, pp. 1361-1364.

LEDUC, G., VIDAL. L., TACHIKAWA. K., ROSTEK, F., SONZOGNI. C., BEAUFORT, L., BARD, E. (2007): Moisture transport across Central America as a positive feedback on abrupt climatic changes. Nature, 445, pp. 908-911.

LEDUC, G., SCHNEIDER, R., KIM, J.-H., LOHMANN, G. (2010): Holocene and Eemian sea surface temperature trends as revealed by alkenone and $\mathrm{Mg} / \mathrm{Ca}$ paleothermometry. Quaternary Science Reviews, 29, pp. 989-1004.

LJUNGQVIST, F.C. (2009): Temperature proxy records covering the last two millennia: a tabular and visual overview. Geografiska Annaler, 91A, pp. 11-29.

LUBINSKI, D.J., FORMAN, S.L., MILLER, G.H. (1999): Holocene glacier and climate fluctuations on Franz Josef Land, Arctic Russia, $80^{\circ}$ N. Quaternary Science Reviews, 18, pp. 85-108.

MACDONALD, G.M., VELICHKO, A.A., KREMENETSKI, C.V., BORISOVA, O.K., GOLEVA, A.A., ANDREEV, A.A., CWYNAR, L.C., RIDING, R.T., FORMAN, S.L., EDWARDS, T.W.D., ARAVENA, R., HAMMARLUND, D., SZEICZ, J.M., GATTAULIN, V.N. (2000): Holocene treeline history and climate change across northern Eurasia. Quaternary Research, 53, pp. 302-311.

MARTRAT, B., GRIMALT, J.O., LOPEZ-MARTINEZ, C., CACHO, I., SIERRO, F.J., FLORES, J.A., ZAHN, R., CANALS, M., CURTIS, J.H. HODELL, D.A. (2004): Abrupt temperature changes in the western Mediterranean over the past 250,000 years. Science, 306, pp. 1762-1765.

MASSON-DELMOTTE, V., JOUZEL, J., LANDAIS, A., STIEVENARD, M., JOHNSEN, S.J., WHITE, J.W.C., SVEINBJÖRNSDÓTTIR, A., FUHRER, K. (2005): Deuterium excess reveals millennial and orbital scale fluctuations of Greenland moisture origin. Science, 309, pp. 118-121.

MASSON, V., VIMEUX, F., JOUZEL, J., MORGAN, V., DELMOTTE, M., CIAIS, P., HAMMER, C., JOHNSEN, S., LIPENKOV, V.Y., MOSLEY-THOMPSON, E., PETIT, J.-R., STEIG, E.J., STIEVENARD, M., VAIKMAE, R. (2000): Holocene climate variability in Antarctica based on 11 ice-core isotopic records. Quaternary Research, 54, pp. 348-358.

MATTHEWS, J.A., BRIFFA, K.R. (2005): The 'Little Ice Age': Re-evaluation of an evolving concept. Geografiska Annaler, 87A, pp. 17-36.

MENOUNOS, B., CLAGUE J.J., OSBORN G.D., LUCKMAN B.H. (2009): Holocene and Latest Pleistocene Glacier Fluctuations in the Canadian Cordillera. Quaternary Science Reviews, 28, pp. 2049-2074.

MULLER, S.D., RICHARD, P.J.H., GUIOT, J., DE BEAULIEU, J.-L., FORTIN, D. (2003): Postglacial climate in the St. Lawrence lowlands, southern Quebec: pollen and lake-level evidence. Palaeogeography, Palaeoclimatology, Palaeoecology, 193, pp. 51-72.

NAKAGAWA, T., TARASOV, P.E., NISHIDA, K., GOTANDA, K., YASUDA, Y. (2002): Quantitative pollen-based climate reconstruction in central Japan: application to surface and Late Quaternary spectra. Quaternary Science Reviews, 21, pp. 2099-2113.

NESJE, A. (2009): Latest Pleistocene and Holocene alpine glacier fluctuations in Scandinavia. Quaternary Science Reviews, 28, pp. 2119-2136.

NRC (NATIONAL RESEARCH COUNCIL; 2006): Surface temperature reconstructions for the last 2,000 years. Washington, DC: National Academies Press, 196 pp.

OJALA, A.E.K., ALENIUS, T., SEPPÄ, H., GIESECKE, T. (2008): Integrated varve and pollen-based temperature reconstruction from Finland: evidence for Holocene seasonal temperature patterns at high latitudes. The Holocene, 18, pp. 529-538. 
ORTEGA-ROSAS, C.I., GUIOT, J., PEÑALBA, M.C., ORTIZ-ACOSTA, M.E. (2008): Biomization and quantitative climate reconstruction techniques in northwestern Mexico-With an application to four Holocene pollen sequences. Global and Planetary Change, 61, pp. 242-266.

PAHNKE, K., SACHS, J.P., KEIGWIN, L., TIMMERMANN, A., XIE, S.-P. (2007): Eastern tropical Pacific hydrologic changes during the past 27,000 years from $\mathrm{D} / \mathrm{H}$ ratios in alkenones. Paleoceanography, 22, PA4214.

PEÑALBA, M.C., ARNOLD, M., GUIOT, J., DUPLESSY, J.C., BEAULIEU, J.L. (1997): Termination of the last glaciation in the Iberian Peninsula inferred from the pollen sequence of Quintanar de la Sierra. Quaternary Research, 48, pp. 205-214.

PEYRON, O., JOLLY, D., BRACONNOT, P., BONNEFILLE, R., GUIOT, J., WIRRMANN, D., CHALIÉ, F. (2006): Quantitative reconstructions of annual rainfall in Africa 6000 years ago: model-data comparison. Journal of Geophysical Research, 111, D24110.

POTITO, A.P., PORINCHU, D.F., MACDONALD, G.M., MOSER, K.A. (2006): A late Quaternary chironomid-inferred temperature record from the Sierra Nevada, California: connections to northeast Pacific sea surface temperatures. Quaternary Research, 66, pp. 356-363.

POWERS, L.A., JOHNSON, T.C., WERNE, J.P., CASTAÑEDA, I.S., HOPMANS, E.C., SINNINGHE DAMSTÉ, J.S., SCHOUTEN, S. (2005): Large temperature variability in the southern African tropics since the Last Glacial Maximum. Geophysical Research Letters, 32, L08706. doi:10.1029/2004GL022014.

RENSSEN, H., SEPPÄ, H., HEIRI, O., ROCHE, D.M., GOOSSE, H., FICHEFET, T. (2009): The spatial and temporal complexity of Holocene thermal maximum. Nature Geoscience, 2, pp. 411-414

RODBELL, D.T., SMITH, J.A., MARK, B.G. (2009): Glaciation in the Andes during the Lateglacial and Holocene. Quaternary Science Reviews, 28, pp. 2165-2212.

RÖTHLISBERGER, F., GEYH, M.A. (1985): Glacier variations in Himalayas and Karakoran. Zeitschrift für Gletscherkunde und Glazialgeologie, 21, pp. 237-249.

RÜHLEMANN, C., MULITZA, S., MÜLLER, P.J., WEFER, G., ZAHN, R. (1999): Warming of the tropical Atlantic Ocean and slowdown of thermohaline circulation during the last deglaciation. Nature, 402, pp. 511-514.

SACHS, J.P. (2007): Cooling of Northwest Atlantic slope waters during the Holocene. Geophysical Research Letters, 34, L03609. doi:10.1029/2006GL028495.

SARMAJA-KORJONEN, K., SEPPÄ, H. (2007): Abrupt and consistent responses of aquatic and terrestrial ecosystems to the 8200 cal. yr BP cold event: a lacustrine record from Lake Arapisto, Finland. The Holocene, 17, pp. 455-464.

SCHEFUß, E., SCHOUTEN, S., SCHNEIDER, R.R. (2005): Climatic controls on central African hydrology during the last 20,000 years. Nature, 437, pp. 1003-1006.

SEPPÄ, H., POSKA, A. (2004): Holocene annual mean temperature changes in Estonia and their relationship to past solar insolation and atmospheric circulation patterns. Quaternary Research, 61, pp. 22-31.

SEPPÄ, H., HAMMARLUND, D., ANTONSSON, K. (2005): Low-frequency and high-frequency changes in temperature and effective humidity during the Holocene in southcentral Sweden: implications for atmospheric and oceanic forcings of climate. Climate Dynamics, 25, pp. 285-297.

SEPPÄ, H., BJUNE, A.E., TELFORD, R.J., BIRKS, H.J.B., VESKI, S. (2009): Last ninethousand years of temperature variability in Northern Europe. Climate of the Past, 5, pp. 523-535.

SHAKUN, J.D., CARLSON, A.E. (2010): A global perspective on Last Glacial Maximum to Holocene next term climate change. Quaternary Science Reviews, 29, pp. 1801-1816.

SHEVENELL, A.E., INGALLS, A., DOMACK, E. (2007): Orbital and atmospheric forcing of western Antarctic Peninsula climate in the Holocene: The TEX $_{86}$ paleotemperature record of Palmer Deep, in Antarctica. In: Raymond, C.R. et al. (eds.): A Keystone in a Changing World. Online Proceedings of the 10th ISAES X, USGS Open-File Report 2007, p. 1047.

SOLOMON, S., QIN, D., MANNING, M., CHEN, Z., MARQUIS, M., AVERYT, K.B., TIGNOR, M., MILLER, H.L. (eds. 2007): Climate Change 2007: The physical science basis. Con- 
tribution of working group I to the fourth assessment report of the Intergovernmental Panel on Climate Change, IPCC, Cambridge and New York, Cambridge University Press, $996 \mathrm{pp}$.

STOTT, L.D., CANNARIATO, K.G., THUNELL, R., HAUG, G.H., KOUTAVAS, A., LUND, S. (2004): Decline of surface temperature and salinity in the western tropical Pacific Ocean in the Holocene epoch. Nature, 431, pp. 56-59.

SUNDQVIST, H.S., ZHANG, Q., MOBERG, A., HOLMGREN, K., KÖRNICH, H., NILSSON, J., BRATTSTRÖM, G. (2010): Climate change between the mid and late Holocene in northern high latitudes - Part 1: Survey of temperature and precipitation proxy data. Climate of the Past, 6, pp. 591-608.

SVENDSEN, J.I. MANGERUD, J. (1997): Holocene glacial and climatic variations on Spitsbergen, Svalbard. The Holocene, 7, pp. 45-57.

TANG, L.Y., SHEN, C.M., LIU, K.B., OVERPECK, J.T. (1999): New high-resolution pollen records from two lakes in Xizang (Tibet). Acta Botanica Sinica, 41, pp. 896-902.

TARASOV, P., GUIOT, J., CHEDDADI, R., ANDREEV, A.A., BEZUSKO, L., BLYAKHARCHUK, T., DOROFEYUK, N., FILIMONOVA, L., VOLKOVA, V., ZERNITSKAYA, V. (1999): Climate in Northern Eurasia 6000 years ago reconstructed from pollen data. Earth and Planetary Science Letters, 171, pp. 635-645.

TARASOV, P., BEZRUKOVA, E., KARABANOV, E., NAKAGAWA, T., WAGNER, M., KULAGINA, N., LETUNOVA, P., ABZAEVA, A., GRANOSZEWSKI, W., RIEDEL, F. (2007): Vegetation and climate dynamics during the Holocene and Eemian interglacials derived from Lake Baikal pollen records. Palaeogeography, Palaeoclimatology, Palaeoecology, 252, pp. 440-457.

TIERNEY, J.E., RUSSELL, J.M., HUANG, Y., SINNINGHE DAMSTÉ, J.S., HOPMANS, E.C., COHEN, A.S. (2008): Northern Hemisphere controls on tropical southeast African climate during the past 60,000 years. Science, 322 , pp. $252-255$.

VIAU, A.E., GAJEWSKI, K., SAWADA, M.C., BUNBURY, J. (2008): Low-and-high-frequency climate variability in Eastern Beringia during the past 25,000 years. Canadian Journal of Earth Sciences. 45, pp. 1435-1453.

VIAU, A.E., GAJEWSKI, K., SAWADA, M.C., FINES, P. (2006): Millennial-scale temperature variability in North America during the Holocene. Journal of Geophysical Research, 111, D09102, doi:10.1029/2005JD006031.

VIAU, A.E., GAJEWSKI, K. (2009): Reconstructing Millennial, Regional: Paleoclimates of Boreal Canada during the Holocene. Journal of Climate, 22, pp. 316-330.

WANNER, H., BEER, J., BÜTIKOFER, J. CROWLEY, T., CUBASCH, U., FLÜCKIGER, J., GOOSSE, H., GROSJEAN, M., JOOS, F., KAPLAN, J.O., KÜTTEL, M., MÜLLER, S., PENTICE, C. SOLOMINA, O., STOCKER, T., TARASOV, P., WAGNER, M., WIDMANN, M. (2008): Mid to late Holocene climate change - an overview. Quaternary Science Reviews, 27, pp. 1791-1828.

WANNER H., BÜTIKOFER, J. (2008): Holocene bond cycles: Real or imaginary? Geografie, 113, pp. 338-350.

WELDEAB, S., LEA, D.W., SCHNEIDER, R.R., ADNERSEN, N. (2007): 155,000 years of West African monsoon and Ocean thermal evolution. Science, 316, pp. 1303-1307.

WIDMANN, M. (2009): Delayed Holocene warming. Nature Geoscience, 2, pp. 380-381.

WILMSHURST, J.M., MCGLONE, M.S., LEATHWICK, J.R., NEWNHAM, R.M. (2007): A pre-deforestation pollen-climate calibration model for New Zealand and quantitative temperature reconstructions for the past 18000 years BP. Journal of Quaternary Science, 22 , pp. $535-547$.

VINTHER, B.M., BUCHARDT, S.L., CLAUSEN, H.B., DAHL-JENSEN, D., JOHNSEN, S.J., FISHER, D. A., KOERNER, R.M., RAYNAUD, D., LIPENKOV, V., ANDERSEN, K.K., BLUNIER, T., RASMUSSEN, S.O., STEFFENSEN, J.P., SVENSSON, A.M. (2009): Holocene thinning of the Greenland ice sheet. Nature, 461, pp. 385-388.

WILLIAMS, P.W., KING, D.N.T., ZHAO, J.X. COLLERSON, K.D. (2004): Speleothem master chronologies: combined Holocene ${ }^{18} \mathrm{O}$ and ${ }^{13} \mathrm{C}$ records from the North Island of New Zealand and their palaeoenvironmental interpretation. The Holocene, 14, pp. 194-208.

WU, H., GUIOT, J., BREWER, S., GUO, Z. (2007): Climatic changes in Eurasia and Africa at the Last Glacial Maximum and mid-Holocene: reconstruction from pollen data using inverse vegetation modelling. Climate Dynamics, 29, pp. 211-229. 
XIA, Q., ZHAO, J.-X., COLLERSON, K.D. (2001): Early-Mid Holocene climatic variations in Tasmania, Australia: multi-proxy records in a stalagmite from Lynds Cave. Earth and Planetary Science Letters, 194, pp. 177-187.

Shrnutí

\section{ČASOPROSTOROVÝ MODEL TEPLOTNÍCH MAXIM STŘEDNÍHO HOLOCÉNU}

Jak je zdůrazněno $\mathrm{v}$ usnesení Mezivládního panelu pro změny klimatu (IPCC) $\mathrm{z}$ roku 2007, jsou naše znalosti o vývoji teplot během období holocénu v globálním i regionálním měřítku stále omezené. Víme, že během středního holocénu byla teplotní maxima (přibližně 8-5 tisíc let před současností) některých oblastí, alespoň během určitých období, o několik stupňů Celsia vyšší než dnes, a to v důsledku změn dráhových elementů Země. Časoprostorový model tohoto oteplování však není stále ještě dostatečně jasný. Hlavním problémem při porozumění klimatu středního holocénu je převaha paleoklimatických záznamů specifických pro určitá období (např. léto) a omezené množství údajů z nižších zeměpisných šířek. Tento nedostatek adekvátních kvantitativních paleoklimatických dat, obzvláště z jižní polokoule, spolu s neschopností obecných modelů cirkulace a energetické bilance simulovat globální průměrné teploty vyšší než současné, vedl k závěru, že teplotní maximum středního holocénu se v globálním měřítku s velkou pravděpodobností neobjevilo synchronně. Dostupné teplotní rekonstrukce však samy o sobě nejsou v tomto ohledu přesvědčivé, mnohé $\mathrm{z}$ nich naznačují, že teplotní maximum středního holocénu se objevilo zároveň v různých částech světa.

Článek předkládá posouzení časoprostorových modelů teplotního maxima středního holocénu v 60 rekonstrukcích ročních teplot z posledních 10 tisíc let před současností $\mathrm{z}$ různých oblastí světa, které byly $\mathrm{v}$ posledních letech publikovány $\mathrm{v}$ odborné literatuře. $\mathrm{Z}$ těchto 60 záznamů je 37 pevninských a 23 mořských. Analýza zhodnotila souvislosti mezi záznamy s teplotami minimálně o 1 , resp. o $2^{\circ} \mathrm{C}$ vyššími než preindustriální (kolem roku 1750). Abychom zachytili pouze změny v ročních teplotách, vyhnuli jsme se všem sezónním rekonstrukcím. Na počátku středního holocénu (10-8 tisíc let před současností) se projevuje silně heterogenním model s oblastmi teplot jak mnohem vyšších, tak mnohem nižších než preindustriální (kolem roku 1750). Poslední období středního holocénu (7-4 tisíc let před současností) však vykazuje náznaky jistým zpo̊sobem více koherentního globálního teplotního maxima, než se doposud uvádělo.

Těchto 60 posuzovaných záznamů naznačuje, že průměrné roční teploty středního holocénu mohly překročit preindustriální teploty nejen během léta ve vyšších zeměpisných šířkách, ale také během ostatních období a v dalších částech světa. Tento výsledek se dobře shoduje s paleoteplotními záznamy z vrtů, které ukazují, že průměrné globální teploty ve středním holocénu byly pravděpodobně alespoň o $1^{\circ} \mathrm{C}$ vyšší, než preindustriální. Pozornost zasluhuje skutečnost, že v těchto 60 diskutovaných záznamech se maximum oteplení projevilo dříve v mnoha záznamech mořských než kontinentálních.

Obr. 1 -Rozmístění 60 paleoteplotních rekonstrukcí uvedených v tabulce 1a-b a na obrázku $2 \mathrm{a}-\mathrm{b}$.

Obr. 2 -Období vyznačená tmavě šedou: nejméně $2{ }^{\circ} \mathrm{C}$ nad preindustriálními teplotami. Období označená šedě: nejméně $1^{\circ} \mathrm{C}$ nad preindustriálními teplotami. Období vyznačená světle šedě: nejméně $1^{\circ} \mathrm{C}$ pod hodnotami preindustriálními. Období s teplotami, které se od preindustriálních liší o méně než $1^{\circ} \mathrm{C}$, nejsou uvedena.

Obr. 3 - Počet záznamů během různých období s hodnotami nejméně $2^{\circ} \mathrm{C}$ nad, nejméně $1^{\circ} \mathrm{C}$ nad nebo nejméně $1^{\circ} \mathrm{C}$ pod preindustriálními hodnotami. 
Authors' affiliations: Department of History, Stockholm University, SE-106 91 Stockholm, Sweden; e-mail: fredrik.c.l@historia.su.se.

Initial submission, 6 October 2009; final acceptance, 22 February 2011.

Please cite this article as:

LJUNGQVIST, F.C. (2011): The Spatio-Temporal Pattern of the Mid-Holocene Thermal Maximum. Geografie, 116, No. 2, pp. 91-110. 